\title{
Humanization in the work of nursing faculty
}

\author{
A humanização no trabalho docente de enfermagem \\ Humanización en el trabajo docente de enfermería
}

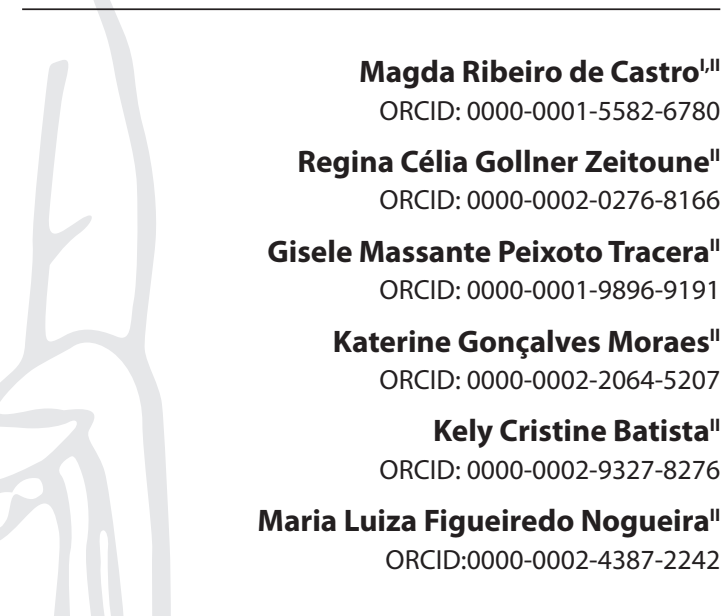

'Universidade Federal do Espírito Santo. Vitória, Espírito Santo, Brazil.

"Universidade Federal do Rio de Janeiro. Rio de Janeiro, Rio de Janeiro, Brazil.

How to cite this article:

Castro MR, Zeitoune RCG, Tracera GMP, Moraes KG Batista KC, Nogueira MLF. Humanization in the work of nursing faculty. Rev Bras Enferm. 2020;73(1):e20170855.

doi: http://dx.doi.org/10.1590/0034-7167-2017-0855

Corresponding Author: Magda Ribeiro de Castro E-mail: magda.soares@ufes.br

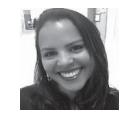

EDITOR IN CHIEF: Antonio José de Almeida Filho ASSOCIATE EDITOR: Margarida Vieira

Submission: $01-16-2018$

Approval: 05-21-2019

\section{ABSTRACT}

Objective: To identify how nursing faculty perceive humanization at work; to describe the factors that enhance humanization and its implications on the health of nursing professors. Method: This was a descriptive and exploratory study carried out at a Brazilian public university with 19 nursing professors who answered a semi-structured interview. Thematic analysis was used to process data, yielding three analytical categories. Results: The faculty indicated that humanization at work and the factors that enhance it are associated with interpersonal relationships, including dialogue and respect in work relationships, positively impacting their health. Final considerations: The effective achievement humanization at work is a possibility that generates health and wellbeing for nursing faculty.

Descriptors: Work; Nursing Faculty; Humanization of Care; Occupational Health; Public Policy.

\section{RESUMO}

Objetivo: Identificar a percepção do docente acerca da humanização em seu trabalho; descrever os fatores potencializadores para a humanização e suas implicações para a saúde do trabalhador docente de enfermagem. Método: Estudo descritivo, exploratório, realizado em uma universidade pública brasileira, com dezenove docentes de enfermagem que responderam à entrevista semiestruturada. Utilizou-se a análise temática para o tratamento dos dados, gerando três categorias analíticas. Resultados: Os docentes percebem que a humanização no trabalho e os fatores que a potencializam estão associados às relações interpessoais, abrangendo diálogo e respeito nas relações de trabalho o que implica favoravelmente à saúde do docente. Considerações finais: A efetivação da humanização no trabalho consiste numa possibilidade geradora de saúde e bem-estar para o trabalhador docente de enfermagem.

Descritores: Trabalho; Docentes de Enfermagem; Humanização da Assistência; Saúde do Trabalhador; Política Pública.

\section{RESUMEN}

Objetivo: Identificar la percepción del docente sobre la humanización en su trabajo, describir los factores potenciadores para la humanización y sus implicancias para la salud del trabajador docente de enfermería. Método: Estudio descriptivo, exploratorio, realizado en una universidad pública brasileña con diecinueve docentes de enfermería que respondieron una entrevista semiestructurada. Datos tratados mediante análisis temático, generándose tres categorías analíticas. Resultados: Los docentes perciben que la humanización en el trabajo y los factores que la impulsan están asociados a las relaciones interpersonales, incluyendo al diálogo y al respeto en las relaciones laborales, lo cual impacta positivamente en la salud del docente. Consideraciones finales: La puesta en práctica de la humanización en el trabajo consiste en una posibilidad de promoción de la salud y el bienestar del trabajador docente de enfermería.

Descriptores: Trabajo; Docentes de Enfermería; Humanización de la Atención; Salud Laboral; Política Pública. 


\section{INTRODUCTION}

The present study investigated humanization at work from the perspective of nursing faculty. The topic of humanization "is currently key to health policies"(1) and therefore it is important to deepen research on the matter ${ }^{(2)}$, especially considering that since the creation of the National Humanization Policy (PNH) in 2003," "much has been discussed on the topic, especially from the point of view of patients. However, there are few discussions about the vulnerability of professionals in this context"(2), corroborating the need to expand scientific production about humanization within the scope of work, focusing on workers.

For the purposes of this study, humanization is defined as the recognition of the different subjects implied in the process of health production, including workers, service users and managers. Guided by these subjects' autonomy and protagonism, co-responsibility, the creation of bonds of solidarity, and collective participation in the management process, committed to improving the quality of the ambiance, work conditions, coordinating education processes with health services and practices ${ }^{(3)}$.

The PNH lists the work process as one of the targets of humanization, caring for the democratization of work relationships; strengthening teamwork by fostering groupality; recognizing the value of professionals and the ambiance, organizing healthy and welcoming work places ${ }^{(3)}$.

From this point of view, it is relevant to discuss the $\mathrm{PNH}$ according to how professional conceptualize the issue, bringing into question the elements that inform the specific take that each subject has on humanization ${ }^{(4)}$.

Based on the above, and considering that humanization is the reason and meaning behind nursing work, the participants of the present study were nursing faculty members ${ }^{(5)}$. Professors must deal with humanization as part of their daily work routine, both in academic and professional training ${ }^{(6-7)}$ and when providing care ${ }^{(8)}$.

Furthermore, teaching is an activity conducted with and for others, and the work involves an ongoing process of interacting with students, other faculty members, administrative staff, management and coordination; i.e., this work requires establishing a network of relationships is established ${ }^{(9)}$.

The PNH is a cross-sectional public policy that addresses issues correlated with interpersonal relationships, the environment, the protagonism and autonomy of subjects, fostering respect of workers' subjectivity and their work. Therefore, it is reasonable to apply the precepts of humanization to the teaching activities of nursing faculty, and transposing this policy to the teaching field contributes to the relevance and original nature of this study.

Studying humanization is one of the priorities of Brazilian health policies ${ }^{(10)}$, in alignment with the ideals of the Brazilian Unified Health System (SUS), in addition to contributing and promoting the foundations for reflecting about and discussing occupational health, which is also supported by the National Agenda for Priorities in Health Research ${ }^{(11)}$ and Nursing Research ${ }^{(12)}$, in which areas such as health policy and occupational health are considered strategic.

A review of the scientific literature about humanization showed that there is abundant production about humanization in health care; humanization in health/nursing; academic and professional training, teaching and learning humanization; humanization of care and humanization health care in different hospital settings, focusing primarily on health service users.

These findings corroborate those of a study ${ }^{(7)}$ that found that humanization was a recurring theme in scientific productions involving care and health care. However, there is a paucity of studies about humanization from the perspective of occupational health as a field of knowledge, and scientific production about humanization in the work of nursing faculty is lacking, corroborating the relevance of the present article.

Humanized work positively contributes to improving workers' health and quality of life, as well as their professional practice, because work based on the precepts of humanization has favorable repercussions for workers and institutions.

\section{OBJECTIVE}

To identify the perception of faculty about humanization at work; describe the factors that enhance humanization; and their implications for the occupational health of nursing faculty.

\section{METHOD}

\section{Ethical aspects}

This study abided by all relevant ethical precepts ${ }^{(13)}$ and participants were given codenames ("faculty member") followed by the number of the order in which they were included in the study, which occurred at random. The study was approved by the Research Ethics Committee. Data were collected after participants approved and signed the informed consent form after receiving an explanation about the study. A copy of this term was kept by the researchers.

\section{Type of study}

This was a descriptive and exploratory qualitative study.

\section{Methodological procedures}

\section{Study setting}

The study was conducted in two Nursing Departments of the same public university in the Southeast Region of Brazil, where the motivation for the study emerged.

\section{Source of data}

Nineteen faculty members composed the sample, corresponding to approximately $70 \%$ of those eligible for the study. Inclusion criteria were being a full faculty member who had entered via a civil servant exam; belonging to the departments of nursing; having an academic nursing background; teaching undergraduate and/or graduate programs and also holding administrative positions. The exclusion criterion was being a faculty member on leave from work activities during the period of data collection, which occurred between October and December 2015. A considerable part of the faculty staff was on leave for 
doctoral studies or other reasons during this period, representing a methodological limitation of this study.

\section{Data collection and organization}

Semi-structured interviews were used to collect data, conducted in a private location chosen by the faculty member, and lasted an average of 64 minutes. The interviews were recorded on digital media, fully transcribed, typed and given to each participant for verification and validation of the data, thus ensuring reliability ${ }^{(14)}$.

\section{Data analysis}

Thematic content analysis was used to process, code and categorize the data. To conduct thematic analysis, themes were considered the logging and context unit ${ }^{(15)}$.

Thus, the text corpus was constructed with all the collected data and then coded, thus gaining meaning and enabling the representation of this content, which was grouped by the similarity of ideas or phrases said by the participants. After uncovering the nuclei of meaning of the participants' interviews, the data were aggregated in thematic analysis categories.

\section{RESULTS}

Regarding sociodemographic and work profile of the participants, the nursing faculty of both departments were predominately women $(n=17,98.5 \%)$, married $(n=10,52.6 \%)$ and between 28 and 37 years old $(n=08,42.1 \%)$. Regarding time since graduation from nursing school, the faculty members had graduated 5 to 14 years prior to the interview $(n=08,42.1 \%)$, and had at least 10 years of work experience $(\mathrm{n}=09,47.3 \%)$ at the studied federal university. Fifteen (78.9\%) had had prior experience with teaching before becoming a civil servant at the public university and 13 (68.4\%) held a PhD degree.

The participants performed different types of work activities: teaching undergraduate, graduate and certificate programs; with outreach projects, research and administrative activities, which often occur in succession, overlapped or were even unassociated, certifying the variety of tasks the permeate the work universe of nursing faculty, who reported working an average of 34-hour weeks. It is important to emphasize that all the participants reported taking their academic work home, either at night or on weekends and holidays, and the intensity and frequency of these activities varied among the faculty.

Based on the interviews of the nursing faculty, thematic units emerged that were grouped into three analysis categories: 1 - Humanization in the work of nursing faculty; 2 - factors that enhance humanization in the work of nursing faculty; and 3- Implications of humanization work on the health of nursing faculty. Details of each category are presented below.

\section{Humanization in the work of nursing faculty}

This analytical category expressed the participants' desire for humanized work. The faculty members considered that bonds of solidarity were sometimes created among individuals; however, humanization was not fully present due to enormous "pressure and demands".
[...] Some activities that end up humanizing some moments. During these workshops we create bonds, some solidarity emerges among people and a more humanized environment ends up being created because of this solidarity, these bonds. [...] But this pressure, this demand, it takes away a bit from humanization. (Faculty Member 2)

[...] Sometimes it's there, sometimes it's not. I think it's an exercise. It's our desire to have a humanized work place [... .] it's very difficult. At times you think: 'This is a humanized work place, a good place to work [...] But then at other times you think: 'God, what is this?' So it's always this cyclical situation [...]. (Faculty Member 15)

[...] When you work within the concepts of humanization you break with the power [...] So as you break with some powers, some people accept this and others don't [...] So, that's the process [...] You will never have humanization in your work process if it's not built day after day. (Faculty Member 9)

The participants perceived humanization through embracement in the work environment. They emphasized that they recognized humanization in their work and that in their field, there is great concern about creating pleasant work environments.

That's a tough question [stops to think]. I know this department has its problems [...] But even so Inotice that the faculty is concerned with creating a pleasant work environment, at least in the course I teach [...] I believe that it is practiced, but it exists in me', I cannot confirm that this is the case with my coworkers [...]. (Faculty Member 3)

In particular, I think my work environment is humanized. I think there is comprehension, understanding [...] I feel well here, I feel accepted, which is part of humanization. (Faculty Member 8)

\section{Factors that enhance humanization in the work of nursing faculty}

This second analytical category highlights the factors that enhance humanization in the work of nursing faculty. It includes interpersonal relationships, recognition of the work and workers, and respect for their autonomy and protagonism.

It is important to highlight that in this study, these factors were understood as enhancers of humanization in the work of nursing faculty, because of the understanding that the PNH is based on positivity, the recognition of potential, and on transforming institutional reality to emphasize "what is right".

[...] I think this issue of relationships between peers is important, encouraging healthy interactions [...] One thing that always concerns me is this issue of relationships at work. [...]. (Faculty Member 3)

[...] The most important thing is [...] recognizing other people's work. I think this is really lacking in people, recognizing each other's work, recognizing the value of other people in the group. I think this is important and needs to be developed. (Faculty Member 4)

I believe it's a matter of freedom, autonomy to carry out your work, this makes work more humanized. And the issue of recognition too, if what you do is recognized, I think that does contribute indeed. (Faculty Member 7) 
Interpersonal relationships, shared and decentralized decision-making, shared management, and collaborative work were mentioned by participants as important aspects to effectively creating a humanized work environment.

[...] / think that when coworkers are concerned with another's work in the sense of being able to contribute, help, collaborate, that would be very important for things to flow better. (Faculty Member 6)

[...] Decentralizing responsibilities, sharing decisions, where everyone is important in the process [...]. (Faculty Member 17)

Dialogue was mentioned as an enhancer of humanization, also permeating the sphere of interpersonal relationships.

The main thing is dialogue and interpersonal relationship [...] to seek out possibilities through dialogue. (Faculty Member 5)

Dialogue, good communication, seeing individuals as a whole. Listening to individuals, hearing their demands. (Faculty Member 8)

[...] Spaces for dialogue, because then we can analyze work processes, these are the main things for me. (Faculty Member 15)

Respect among coworkers was also mentioned as an enhancer for achieving humanization at work.

Respecting other people, never mixing the personal with the professional. Giving other people a chance [...] Respect is the foundation of everything! [...]. (Faculty Member 13)

I think we need respect! So, in work relationships [...] respect is essential (Faculty Member 18)

Respect [...] because when there is respect, all the other factors emerge. There is no ethics without respect, no autonomy without respect, no recognition without respect, you can't build commitment without respect [...] There is no way we can even think about humanized work when there is no respect [...]. (Faculty Member 19)

\section{Implications of humanized work on faculty members' health}

This analytical category emphasizes the implications of humanized work on the health of faculty members according to the participants. The faculty reported favorable impacts on their physical and psychological health, resulting in job satisfaction, less illness, and positive contributions to health and wellbeing.

[...] Humanization improves health [...] especially emotional aspects. In a humanized environment, professionals feel recognized and this causes a positive impact on their physical, emotional and spiritual wellbeing. (Faculty Member 5)

[...] The first thing that comes to mind is emotional and psychological health. Professionals go to work with satisfaction, and even though they are overloaded, they will respond adequately. One day or other they'll feel more tired, but they won't be emotionally ill. (Faculty Member 18)

So, humanization proposes health promotion based on daily activities, on interpersonal relationships, it is aligned with more participatory management models, which effectively result in much less illness [...]. (Faculty Member 9)

\section{DISCUSSION}

The sociodemographic and work profiles of the participants showed a predominance of married women, as was the case in other Brazilian studies ${ }^{(16-17)}$ and international research carried out with nursing faculty in Florida, Colorado and Turkey in terms of the expressiveness of married ${ }^{(20)}$ women $^{(18-20)}$.

Regarding age, the findings of this study corroborate those of a study conducted in Turkey with nursing professors ${ }^{(19)}$, which showed relatively young faculty members.

Considering time since graduation and of experience with teaching, the findings are in line with those of a study developed with nursing faculty in Florida ${ }^{(18)}$.

The participants in the present study developed various work activities, often taking on overlapping of roles and taking work home with them, as has been shown in both Brazilian and international studies ${ }^{(18,21-23)}$

Thus, work competes with time that should be used for other non-work activities, as it invaded their private lives and was performed outside of institutionalized work hours ${ }^{(20)}$. In the present study, reading, researching and preparing and correcting academic activities, among others, occurred outside the institutional setting, as verified in other studies ${ }^{(20,24)}$.

The faculty's perception of humanization at work involved aspects relative to bonds, nurturing, solidarity in daily professional practice, respect in interpersonal relationships, and collaborative work processes with shared management.

Solidarity stood out in the smaller groups, a common feature in the case where the same course was taught by several faculty members. In the studied time period, this number ranged between two to eight professors teaching the same course part of the undergraduate curriculum. Thus, among small groups, bonds of solidarity were more viable, in harmony with the precepts of humanization.

Duarte and Noro $^{(25)}$ affirmed that human relationships within the work place can hinder the process of reaching humanization, because"in team work, the objectives before a given reality must be similar so that all can reach a greater objective, that of making humanization a concrete part of professional practice.

However, there are no rules or formulas in the humanization process, because, essentially, it depends on individuals and their conceptions about humanization. Thus, it is a wide-reaching, lengthy and complex process, which faces resistance by many professionals because it requires behavioral changes that cause insecurity ${ }^{(25)}$.

The concept of humanization is aligned with various proposals for changing relationships between professionals and managers. It clearly involves investing in relational technologies, especially the technologies of listening, embracement, dialogue and negotiation ${ }^{(26)}$.

It is also important to consider that the faculty's work is intangible, and therefore, it is a social action by nature ${ }^{(27)}$. The practice of teaching requires forming relationships with students, other professors, managers, other workers and, in some cases, family members.

Thus, as demonstrated in the results, relational issues are an important component of teaching practice, and good interpersonal 
relationships and effective communication contribute to humanization at work ${ }^{(28)}$.

Based on the interviews with the faculty, relational factors were frequently mentioned as enhancers of humanization at work, with emphasis to the recognition of work and workers, autonomy, and protagonism, principles of the $\mathrm{PNH}$, in which recognition is associated with both workers and their work.

Recognition is an attitude that adds value to human beings ${ }^{(2)}$, in line with the assumptions of the $\mathrm{PNH}^{(3)}$. It is based on the belief that individuals must be recognized as unique, free, equal beings, worthy of respect ${ }^{(29)}$. Therefore, recognition contributes to humanization, because the humanist conception of recognition as defined here is interested in the qualities of singular beings, in which recognition is directed at individuals.

Researchers ${ }^{(30)}$ have shown that there are favorable health-producing work possibilities. This is based on the understanding that the challenges imposed by daily work in the health field, which is constantly changing, are associated with human potential to create and reinvent new processes that meet needs.

In this direction of creating and recreating human potential, autonomy and protagonism come into play, contributing to healthier group interactions in which everyone is considered important, and is valued and recognized in the work process.

The answers given by the participants expressed the idea of contribution and cooperation as enhancing humanization at work, while also facilitating the construction of solidarity.

Cooperation enables collective construction and is based on the understanding of work as a form of relating with other people. Such cooperation is based on the assumption of a collective, because to work is the experience lived in the work routine, and interacting means coexisting ${ }^{(30)}$.

In this interaction, the faculty understood dialogue as a possibility for humanization at work, converging with the PHN which recommends that quality dialogue must be fostered ${ }^{(31)}$. Work is considered an important human activity in the life of subjects, as life is dialogic in nature ${ }^{(32)}$.

Along these lines, it is strategic to create spaces for collective debates that can spread the word and consequently contribute to health promotion in the work place ${ }^{(30)}$. Thus, communicative actions are essential, as set forth in the PHN principles, which enable the production of health among workers and the expression of their subjectivity.

In this perspective, it is important to emphasize the concept of network, referring to the active participation of subjects to address situations that arise from work. Thus, it is defined "grouplet that is updated as a collectivity with agency and in transformation $^{\prime \prime(30)}$. The subjects that compose this network are workers with protagonist roles who affirm their capacity to intervene in decision-making processes in their work. Thus, the elements considered essential to humanization enter the scene, favoring the recognition of workers as well as their work.

Once these conditions are ensured, workers will have more power to act, enhancing their professional practice, fostering wellbeing and health in their work, all based on the PNH precepts.

As verified in the present study, the literature highlights the relevance of dialogue to humanization, and the $\mathrm{PNH}$ encourages communication to construct collective processes to address power relationships, work and affection that often inhibit autonomy and the co-responsibility of professionals at work, producing dehumanizing attitudes and practice ${ }^{(31)}$. The same document states that it is necessary to recognize that differences can converse and that, together, different types of knowledge can produce health in a more co-responsible way ${ }^{(31)}$.

Thus, creating different spaces for subjects to meet, constructing shared knowledge and networked team work are some of the ways to operationalize the precepts of humanization at work ${ }^{(3)}$

In the present study, according to the faculty, respect was essential to humanization at work, indicated as essential to relationships. Corroborating this finding, Sanches et al ${ }^{(33)}$ state that this construction must be collective and participatory, seeking to embrace and respect the values, beliefs, culture and life expectations unique to each person. Fernandes and Ferreira ${ }^{(34)}$ associated humanization with quality of life, emphasizing that positive relationships, marked by friendship, cooperation, respect and mutual trust, contribute to greater feeling of job satisfaction and wellbeing at work.

Achieving a healthy work environment requires establishing work conditions based on moral and ethical principles and respect for others, considering each individual as unique, with a group commitment to ethics, solidarity, love of others, dignity, recognizing the value of oneself and others, citizenship and respect ${ }^{(35)}$.

Martins et al ${ }^{(28)}$ concluded that good interpersonal relationships and effective communication contribute to humanization, because to humanize means providing the necessary room for communications, an essential tool for humanization which depends on their ability to speak and listen, because there is no humanization without communication.

Regarding the implications for humanization at work, the participants reported favorable repercussions on their health. The literature indicates that "work contexts can act as sources of health or illness both in terms of overall health and mental health"(36).

Dejours, Abdoucheli and Jayet ${ }^{(37)}$ reinforce the impact of work organization on the psyche and investigate how workers are able to reach certain psychological balance even when submitted to destructuring organizations. Work organization is divided into workers, the content of tasks, modalities of command, and hierarchal and power relationships ${ }^{(38)}$.

From this perspective, Dejours ${ }^{(38)}$ emphasizes that work organization acts directly on the psychosomatic economy of workers, corroborating the conception that workers can be affected by organization depending on how they are instituted, impacting health both positively and negatively.

Thus, rigid and inflexible organizations can harm workers. However, flexible work organizations that allow workers to manifest their subjectivity, creativity, in which work is invented and re-invented, and protagonism is exercised, can positively impact the health and wellbeing of individuals ${ }^{(38)}$. Dejours states that work is never neutral in terms of health, as it can represent either a source of pleasure or suffering, positively or negatively affecting significant spheres of human life ${ }^{(38)}$.

Thus, pleasurable work is that in which workers are responsible for an important part of its conception and that promotes inventiveness, creativity, problem-solving capacity and the use of intelligence ${ }^{(39)}$, as recommended by the $\mathrm{PNH}$. 


\section{Limitations of the study}

The findings of the present study cannot be generalized, as the participants belonged to a single setting. Thus, further studies focused on humanization of the work of nursing faculty should be conducted. However, this limitation did not compromise the originality and relevance of the investigation.

\section{Contributions to the area of nursing and health}

The present study raised important issues to achieving humanization at work, specifically that of nursing faculty. It especially showed the relevance of interpersonal relationships in this context.

\section{FINAL CONSIDERATIONS}

The study verified that among the studied sample, humanization was not fully implemented, and interpersonal relationships were pointed out as the greatest mean to achieving this goal, which includes autonomy, protagonism, recognition of workers, the importance of cooperation in the work process, of quality dialogue and respect in work relationships, in which the active participation of all workers is important.

Lack of these principles favors destructuring work organizations that can result in the perception of dehumanization at work.

However, humanization at work was believed to positively impact worker health, reducing illness, contributing to wellbeing and to making work relationships more democratic, fostering collective work and the recognition of all the subjects involved in the process, allowing for the organization of healthy and embracing work places, as recommended by the $\mathrm{PNH}$.

The present study confirms the viability and relevance of studying humanization at work and supports the expansion of studies along this vein. Humanization can contribute to occupational health, because work is a space for collective creation. Thus, further studies about the theme are recommended to expand the discussion to include other settings and workers, increasing reflections about humanization at work.

\section{REFERÊNCIAS}

1. Ferreira LR, Artmann E. Pronouncements on humanization: professionals and users in a complex health institution. Cien Saude Colet. 2018;23(5):1437-50. doi: 10.1590/1413-81232018235.14162016

2. Fontana RT. Humanização no processo de trabalho em enfermagem: uma reflexão. Rev Rene [Internet]. 2010[cited 2014 Jan 20];11(1):200-7. Available from: http://www.periodicos.ufc.br/rene/article/view/4506

3. Ministério da Saúde (BR). HumanizaSUS: Documento base para gestores e trabalhadores do SUS [Internet]. Brasília: Ministério da Saúde; 2010 [cited 2014 May 13]. Available from: http://bvsms.saude.gov.br/bvs/publicacoes/humanizasus_documento_gestores_trabalhadores_ sus.pdf

4. Chernicharo IM, Freitas FDS, Ferreira MA. Humanização no cuidado de enfermagem: contribuição ao debate sobre a Política Nacional de Humanização. Rev Bras Enferm. 2013;66(4):564-70. doi: 10.1590/S0034-71672013000400015

5. Collet N, Rozendo CA. Humanização e trabalho na enfermagem. Rev Bras Enferm. 2003;56(2):189-92. doi: 10.1590/ S0034-71672003000200016

6. Medeiros LMOP, Batista SHSS. Humanização na formação e no trabalho em saúde: uma análise de literatura. Trab Educ Saúde. 2016;14(3):925-51. doi: 10.1590/1981-7746-sol00022

7. Almeida DV, Chaves EC. Teaching humanization in undergraduate nursing course subjects. Invest Educ Enferm [Internet]. 2013 [cited 2014 Jan 20];31(1):44-53. Available from: http://www.scielo.org.co/scielo.php?script=sci_arttext\&pid=S0120-53072013000100006

8. Barbosa GC, Meneguim S, Lima SAM, Moreno V. Política Nacional de Humanização e formação dos profissionais de saúde: revisão integrativa. Rev Bras Enferm. 2013;66(1):123-7. doi: 10.1590/S0034-71672013000100019

9. Tardif M, Lessard C. O trabalho docente: elementos para uma teoria da docência como profissão de interações humanas. $8^{\mathrm{a}}$ ed. Petrópolis: Vozes; 2013

10. Reis LS, Silva EF, Waterkemper R, Lorenzini E, Cecchetto FH. Humanization of healthcare perception of a nursing team in a neonatal and pediatric intensive care unit. Rev Gaúcha Enferm. 2013;34(2):118-24. doi: 10.1590/S1983-14472013000200015

11. Ministério da Saúde (BR). Agenda Nacional de Prioridades de Pesquisa em Saúde [Internet]. Brasília: Ministério da Saúde; 2015 [cited 2015 May 13]. Available from: http://brasil.evipnet.org/wp-content/uploads/2017/07/ANPPS.pdf

12. Cassiani SHB, Bassalobre-Garcia A, Reveiz L. Universal Access to Health and Universal Health Coverage: identification of nursing research priorities in Latin America. Rev Latino-Am Enferm. 2015;23(6):1195-208. doi: 10.1590/0104-1169.1075.2667

13. Ministério da Saúde (BR). Conselho Nacional de Saúde. Resolução n 466, de 12 de dezembro de 2012. Aprova diretrizes e normas regulamentadoras de pesquisas envolvendo seres humanos [Internet]. Brasília; 2012 [cited 2015 May 13]. Available from: https://conselho. saude.gov.br/resolucoes/2012/Reso466.pdf

14. Breakwell GM, Fife-Schaw C, Hammond S, Smith JA. Métodos de pesquisa em Psicologia. 3a ed. Porto Alegre: Artmed; 2010.

15. Bardin L. Análise de Conteúdo: Ed. Revista e Ampliada. Lisboa: Edições 70; 2011.

16. Conceição MR, Costa MS, Almeida MI, Souza AMA, Cavalcante MBPT, Alves MDS. Qualidade de vida do enfermeiro no trabalho docente: 
estudo com o Whoqol-bref. Esc Anna Nery Rev Enferm. 2012;16(2):320-5. doi: 10.1590/S1414-81452012000200016

17. Souza SM, Souto LES, Lima CA, Lacerda MKS, Vieira MA, Costa FM. Caracterização sociodemográfica de docentes da área da saúde. Rev Norte Min Enferm [Internet]. 2015 [cited 2017 Aug 23]; 4(1):15-28. Available from: http://www.renome.unimontes.br/index.php/renome/ article/view/88

18. Gwyn PG. The quality of mentoring relationships' impact on the occupational commitment of nursing faculty. J Prof Nurs. 2011;27(5):292-8. doi: 10.1016/j.profnurs.2011.03.008

19. Kantek F, Baykal U. Organizational culture in nursing schools in Turkey: faculty members' perspectives. Int Nurs Rev. 2009;56(3):306-12. doi: 10.1111/j.1466-7657.2009.00721.x

20. Whalen KS. Work-related stressors experienced by part-time clinical affiliate nursing faculty in baccalaureate education. Int J Nurs Educ Sch. 2009;6(1):1-18. doi: 10.2202/1548-923X.1813

21. Oliveira JM, Santos PF, Feliciano RG, Assis MM, Cortez EA, Valente GSC. Riscos e doenças ocupacionais do docente universitário de enfermagem: implicações na saúde do trabalhador. R Pesq Cuid Fundam. 2013;5(1):3267-75. doi: 10.9789/2175-5361.2013v5n1p3267

22. Soares RJO, Zeitoune RCG, Lisboa MTL, Mauro MYC. Fatores facilitadores e impeditivos no cuidar de si para docentes de enfermagem. Texto Contexto Enferm. 2011;20(4):758-65. doi: 10.1590/S0104-07072011000400015

23. Tschannen D, Anderson C, Strobbe S, Bay E, Bigelow A, Chin Hwa G et al. Scholarly productivity for nursing clinical track faculty. Nurs Outlook. 2014;62(6):475-81. doi: 10.1016/j.outlook.2014.05.006

24. Krueger P, White D, Meaney C, Kwong J, Antao V, Kim F. Predictors of job satisfaction among academic family medicine faculty: Findings from a faculty work-life and leadership survey. Can Fam Physician [Internet]. 2017 [cited 2017 Oct 17];63:177-85. Available from: http://www. cfp.ca/content/cfp/63/3/e177.full.pdf

25. Duarte MLC, Noro A. Humanização: uma leitura a partir da compreensão dos profissionais da enfermagem. Rev Gaúcha Enferm. 2010;31(4):685-92. doi: 10.1590/S1983-14472010000400011

26. Deslandes SF. O projeto ético-político da humanização: conceitos, métodos e identidade. Interface Comunic Saúde Educ. 2005;9(17):389406. doi: 10.1590/S1414-32832005000200017

27. Mendonça Neto OR, Antunes MTP, Vieira AM. Controle do trabalho docente: provocações foucaultianas para análise da gestão universitária. Avaliação. 2015;20(3):665-83. doi: 10.1590/S1414-40772015000300006

28. Martins JT, Galdino MJQ, Garanhani ML, Sammi KM, Trevisan GS. Humanization in the work process in the view of intensive care unit nurses. Cogitare Enferm [Internet]. 2015 [cited 2016 Apr 16];20(3):589-95. Available from: http://www.saude.ufpr.br/portal/revistacogitare/wpcontent/uploads/sites/28/2016/10/41521-162528-1-PB.pdf

29. Bendassolli PF. Reconhecimento no trabalho: perspectivas e questões contemporâneas. Psicol Estud. 2012;17(1):37-46. doi: 10.1590/ S1413-73722012000100005

30. Barros MEB, Santos-Filho SB. O trabalho em saúde nos referenciais da Política Nacional de Humanização: construindo uma metodologia de análise e intervenção. In: Gomez CM, Machado JMH, Pena PGL, editores. Saúde do trabalhador na sociedade brasileira contemporânea. Rio de Janeiro: Fiocruz; 2013. p. 123-41.

31. Ministério da Saúde (BR). HumanizaSUS: Política Nacional de Humanização [Internet]. Brasília: Ministério da Saúde; 2013 [cited 2014 Jan 13 ]. Available from: http://bvsms.saude.gov.br/bvs/publicacoes/politica_nacional_humanizacao_pnh_folheto.pdf

32. Athayde M. Saúde 'mental' e trabalho: questões para discussão no campo da saúde do trabalhador. In: Gomez CM, Machado JMH, Pena PGL, organizadores. Saúde do trabalhador na sociedade brasileira contemporânea. Rio de Janeiro: Fiocruz; 2013. p. 345-68.

33. Sanches RCN, Gerhardt PC, Rêgo AS, Carreira L, Pupulim JSL, Radovanovic CAT. Percepções de profissionais de saúde sobre a humanização em unidade de terapia intensiva adulto. Esc Anna Nery Rev Enferm. 2016;20(1):48-54. doi: 10.5935/1414-8145.20160007

34. Fernandes LC, Ferreira MC. Qualidade de vida no trabalho e risco de adoecimento: estudo no poder judiciário brasileiro. Psicol USP. 2015;26(2):296-306. doi: 10.1590/0103-656420130011

35. Bobroff MCC, Martins JT. Assédio moral, ética e sofrimento no trabalho. Rev Bioét. 2013;21(2):251-8. doi: 10.1590/ S1983-80422013000200008

36. Seligmann-Silva E. Trabalho e desgaste mental: o direito de ser dono de si mesmo. São Paulo: Cortez; 2011.

37. Dejours C, Abdoucheli E, Jayet C. Psicodinâmica do trabalho: contribuições da Escola Dejouriana à análise da relação prazer, sofrimento e trabalho. São Paulo: Atlas; 1994.

38. Dejours C. A loucura do trabalho: estudo de psicopatologia do trabalho. $5^{a}$ ed. São Paulo: Cortez Oboré; 1992.

39. Lacaz FAC, Sato L. Humanização e qualidade do processo de trabalho em saúde. In: Deslandes SF, organizadora. Humanização dos cuidados em saúde: conceitos, dilemas e práticas. Rio de Janeiro: Fiocruz; 2014. p. 109-39. 